\title{
PROSPECTS OF APPLICATION OF TUBES MADE OF DUPLEX STEELS OF A NEW GENERATION IN THE HEAT EXCHANGING EQUIPMENT OF NUCLEAR POWER PLANTS
}

\author{
T.A. Dergach ${ }^{1}$, G.D. Sukhomlyn ${ }^{1}$, S.A. Panchenko ${ }^{2}$, N.E. Kalinina ${ }^{3}$, A.E. Balev ${ }^{4}$, \\ A.V. Krasiuk ${ }^{4}$, V.T. Kalinin 5 \\ ${ }^{1}$ Prydniprovsk State Academy of Civil Engineering and Architecture, Dnipro, Ukraine; \\ ${ }^{2}$ Energobud Management TMM, Kharkiv, Ukraine; \\ ${ }^{3}$ Oles Gonchar Dnipro National University, Dnipro, Ukraine; \\ ${ }^{4}$ Centravis Production Ukraine JSC, Nikopol, Ukraine; \\ ${ }^{5}$ National Metallurgical Academy of Ukraine, Dnipro, Ukraine
}

\begin{abstract}
Prospects of using tubes produced by Centravis Production Ukraine JSC of ferritic-austenitic (duplex) steels of a new generation according to the developed innovative technology in the heat exchanging equipment of nuclear power plants (NPP) were scientifically substantiated based on analysis of scientific and technical literature and the results obtained in comprehensive studies. Comparative corrosion studies of the tubes made of austenitic $\mathrm{Cr}-\mathrm{Ni}$ and Cr-Ni-Mo steels and 02Cr22Ni5NMo3 (UNS S 31803) duplex steel have shown a substantially improved resistance of the latter to intercrystalline, pit and crevice corrosion, corrosion cracking and erosion. Presence of special lowenergy $\gamma-\gamma, \alpha-\alpha$ grain boundaries and $\alpha-\gamma$ interphase boundaries characterized by an increased corrosion resistance and a contribution to the growth of steel durability as a whole was found for the first time in the structure of ferriticaustenitic steels.
\end{abstract}

\section{INTRODUCTION}

Tubes of corrosion resistant austenitic $\mathrm{Cr}-\mathrm{Ni}$ and $\mathrm{Cr}$ Ni-Mo steels (Table 1) are widely used in domestic practice of building NPP heat exchanging equipment. The tube failures are caused by local pit and intercrystalline corrosion (ICC) and corrosion cracking (CC) often originating and developing at the grain boundaries as well as by erosion wear [1-3].

The duplex and super-duplex steels of a new generation cost-effectively doped with nickel are increasingly used abroad as materials for tubes of watercooled steam condensers operated in various industries $[2,4-8]$. These steels were developed to replace more costly and less corrosion resistant austenitic steels.

Advantages of the duplex steels:

- twice higher strength in comparison with austenitic steels [4];

- low sensitivity to CC and ICC in a number of process media [4-7];

- higher resistance to pit and crevice corrosion in chloride-containing media at elevated temperatures as compared to austenitic steels [3-8];

- low coefficient of thermal expansion $\left(13 \cdot 10^{6} /{ }^{\circ} \mathrm{C}\right)$ as compared to that in austenitic steels $\left(18 \cdot 10^{6} /{ }^{\circ} \mathrm{C}\right)$ [6] which makes it possible to use them effectively in building heat exchanging equipment even in the cases of contacting with low alloy steels;

- profitability: at nitrogen content under $0.2 \%$, the content of high-cost nickel in duplex steels is twice less than in conventional $\mathrm{Cr}-\mathrm{Ni}$ and $\mathrm{Cr}-\mathrm{Ni}-\mathrm{Mo}$ austenitic steels.

Advantages of ferritic-austenitic steels include good weldability, malleability, deformability in hot and cold states and high thermal conductivity [6,9].

The study objective: based on the study results, substantiate scientifically efficiency of application of the tubes made of ferritic-austenitic (duplex) steels of a new generation in building the nuclear power plants heat exchanging equipment.

\section{THE PROBLEM STATEMENT}

Corrosion-caused failures of the heat exchanger tubes in the NPP condensers cause significant economic losses because of depressurization and the need for stopping equipment for repair, contamination of the heat carrier and underproduction of electricity. The main unfavorable factors that have a negative effect on corrosion resistance of heat exchangers in conditions of long-term operation include the increased content of chlorides in water (up to $250 \mathrm{mg} / \mathrm{l}$ ), high total mineralization with salts (up to $3000 \mathrm{mg} / \mathrm{l}$ ) and elevated temperature of cooling the water circulating in tubes (up to $100{ }^{\circ} \mathrm{C}$ and even up to $300{ }^{\circ} \mathrm{C}$ at peak loads).

Therefore, heat exchanger tubes must possess the following properties and be made and tested in specified conditions:

- a high resistance to local intercrystalline and pit corrosion, $\mathrm{CC}$ and erosion;

- an effective complex of mechanical properties to prevent mechanical damage by vibration and external mechanical effects;

- a good weldability of the tube material with the tube plate and processability in welding.

The tubes must be manufactured according to the implemented industrial technology and subjected to acceptance corrosion tests with the use of certified equipment.

To substantiate the prospects of using tubes made of duplex steels of a new generation in building the NPP heat exchanging equipment, existing published data were analyzed and comprehensive studies aimed at improvement of qualitative characteristics of these tubes were conducted. 


\section{THE STUDY RESULTS AND THEIR DISCUSSION}

Comparative studies of susceptibility of the tubes made of austenitic steels and ferritic-austenitic (duplex) steels of a new generation to corrosion of various types have been conducted in this study. The cost-effective 02Cr22Ni5NMo3 (UNS S31803/S32205) steel is the most common of these steels (see Table 1).

Table 1

Grades of the corrosion-resistant steels most widely used in the world practice of making heat exchanger tubes

\begin{tabular}{|c|c|c|c|c|c|c|c|c|c|}
\hline \multirow{2}{*}{ Steel grade } & \multirow{2}{*}{ UNS/AISI } & $\mathrm{C}$ & $\mathrm{Cr}$ & $\mathrm{Ni}$ & Mo & $\mathrm{N}$ & \multirow{2}{*}{$\begin{array}{c}\text { PREN }^{*} \\
\%\end{array}$} & \multirow{2}{*}{$\begin{array}{r}\sigma_{0.2} \\
\mathrm{MPa}\end{array}$} & \multirow{2}{*}{$\frac{\sigma_{\mathrm{B}}}{\mathrm{MPa}}$} \\
\hline & & \multicolumn{5}{|c|}{ Element content, $\%$} & & & \\
\hline \multicolumn{10}{|c|}{ Austenitic steels } \\
\hline 03Cr18Ni11 & 304L & $<0.030$ & 18.5 & 10.5 & - & - & $>18$ & 200 & 500 \\
\hline 03Cr17Ni14Mo3 & $316 \mathrm{~L}$ & $<0.030$ & 17 & 11.5 & 2.1 & - & $>24$ & 225 & 520 \\
\hline \multicolumn{10}{|c|}{ Duplex steel } \\
\hline \multirow{2}{*}{ 02Cr22Ni5NMo3 } & S 32205 & \multirow{2}{*}{$<0.030$} & \multirow{2}{*}{22.5} & \multirow{2}{*}{6} & \multirow{2}{*}{3.1} & \multirow{2}{*}{0.17} & \multirow{2}{*}{$>34$} & \multirow{2}{*}{480} & \multirow{2}{*}{680} \\
\hline & S 31803 & & & & & & & & \\
\hline \multicolumn{10}{|c|}{ Super-duplex steel } \\
\hline 02Cr25Ni7NMo4 & S32750 & $<0.030$ & 25.0 & 7 & 4 & 0.3 & $>40$ & 480 & 680 \\
\hline
\end{tabular}

\section{STRUCTURAL FEATURES OF THE DUPLEX STEELS}

A typical structure of ferritic-austenitic steels features alternating ferrite and austenitic phases stretched in the direction of deformation at their optimal percent ratio of 50:50 (Fig. 1,a). Orientation of interphase boundaries in the direction of deformation indicates their higher specific surface energy in comparison with the intergranular boundaries of the $\gamma$ and $\alpha$-phases. The presence of interphase boundaries prevents growth of ferrite $(\alpha)$ and austenite $(\gamma)$ grains during heating and provides high strength properties,

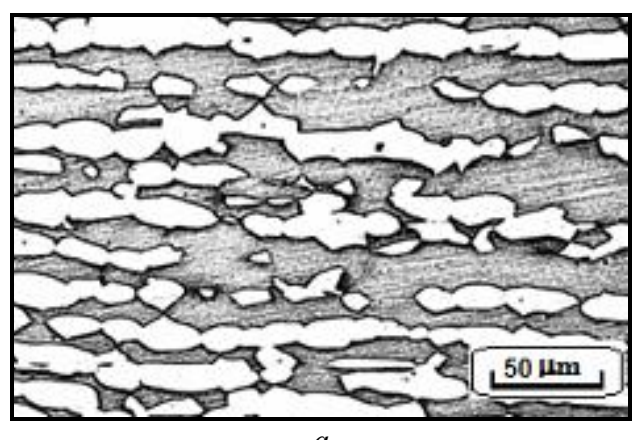

$a$ resistance to corrosion in weakly oxidizing media and $\mathrm{CC}$ of ferritic-austenitic steels.

The main disadvantage of the ferritic-austenitic steels consists in precipitation of intermetallic phases in their structure during heating in the temperature range of $600 \ldots 1000{ }^{\circ} \mathrm{C}$. The high-chromium $\sigma$-phase of the $\mathrm{Fe}-\mathrm{Cr}-\mathrm{Mo}$ alloy causing embrittlement and worsening of corrosion resistance of steels is the most unfavorable [10]. Temperatures from 850 to $950{ }^{\circ} \mathrm{C}$ are the most dangerous from the point of view of the $\sigma$-phase precipitation. At a long-term exposure in a temperature range of $400{ }^{\circ} \mathrm{C}$, intermetallic phases were not observed in the tubes of $02 \mathrm{Cr} 22 \mathrm{Ni} 5 \mathrm{NMo} 3$ steel (see Fig. 1,b).

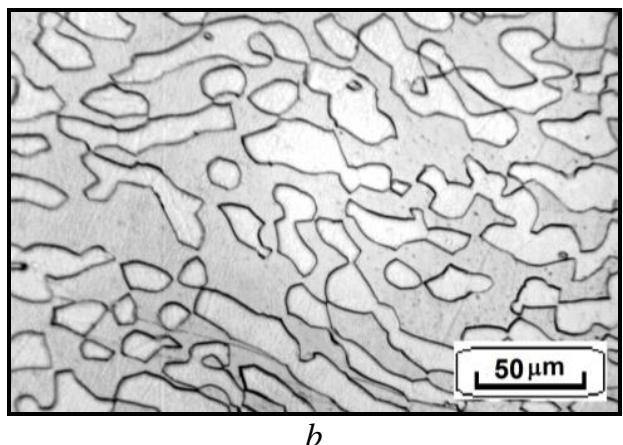

Fig. 1. A typical structure of duplex and super-duplex steels (a); a structure in a specimen of a tube made

of $02 \mathrm{Cr} 22 \mathrm{Ni} 5 \mathrm{NMo} 3$ steel after tempering at $400{ }^{\circ} \mathrm{C}$ for $500 \mathrm{~h}(\mathrm{~b})$

\section{COMPARATIVE ANALYSIS OF CORROSION RESISTANCE \\ OF AUSTENITIC AND DUPLEX STEELS}

Resistance of steels to the most dangerous types of local corrosion (pit and crevice corrosion) occurring in chloride-containing media is determined primarily by their chemical composition (content of chromium, molybdenum, nitrogen) and characterized by the pitting resistance equivalent number (PREN) which is calculated by the formula: PREN = $=\% \mathrm{Cr}+3.3 \times \% \mathrm{Mo}+30 \times \% \mathrm{~N}[6]$.

Calculation of the PREN indicators for a number of the most common austenitic and ferritic-austenitic steels of a new generation shows that their magnitude increases in the following order: $304 \mathrm{~L} \rightarrow 316 \mathrm{~L} \rightarrow 32304$ $\rightarrow$ S32205 and S31803 (02Cr22Ni5NMo3) (see Table 1).
The following is the comparison data of resistance of austenitic and ferritic-austenitic $\mathrm{Cr}-\mathrm{Ni}-\mathrm{Mo}$ steels to pitting which indicates advantage of the latter.

According to the data of [4] obtained in testing for pitting resistance of the specimens of austenitic (03Cr17Ni14Mo3) and ferritic-austenite (02Cr22Ni5NMo3) steels exposed for 270 days to a chloride-containing medium $(60.000 \ldots 80.000 \mathrm{ppm} \mathrm{Cl})$ at a temperature of $55^{\circ} \mathrm{C}$, their weight loss was $17 \mathrm{~g}$ and not more than $1 \mathrm{~g}$, respectively.

The S32205 duplex steel had a significantly more positive pitting potential $(E=+1000 \mathrm{mV})$ compared to the $316 \mathrm{~L}$ austenitic steel $(E=+300 \mathrm{mV})$ in a solution containing $50 \mathrm{~g} / \mathrm{l} \mathrm{NaCl}$ at $\mathrm{pH} 6.4$ and temperature of $50{ }^{\circ} \mathrm{C}[6]$.

The duplex and super-duplex steels were characterized by considerably higher critical 
temperatures of pitting formation compared to the austenitic steels when tested in $0.01 \ldots 2 \% \mathrm{NaCl}$ solutions in the temperature range from 0 to $100{ }^{\circ} \mathrm{C}$ and a potential of $+300 \mathrm{mV}$ [6].

The results of electrochemical studies of crevice corrosion resistance of the austenitic and duplex steel specimens with recording the change in time of their corrosion potentials during a $1000 \mathrm{~h}$ test in a $50 \mathrm{~g} / \mathrm{l}$ $\mathrm{NaCl}$ solution at $50{ }^{\circ} \mathrm{C}$ have shown higher corrosion resistance of the duplex steel. Examination of the $316 \mathrm{~L}$ steel specimens after their testing has revealed crevices. The weight loss was up to $2 \mathrm{mg}$ and corrosion depth in the crevices was $44 \mu \mathrm{m}$. Weight loss and crevice formation were not observed in the UNS S32205 duplex steel specimen.

Comparative data on resistance of austenitic and ferritic-austenitic steels to CC have shown (Fig. 2) that the duplex (S2304, SAF 2205) and super-duplex (SAF 2507) steels were characterized by a significantly higher resistance to $\mathrm{CC}$ in chloride-containing media at elevated temperatures than the austenitic 304L and 316L steels.

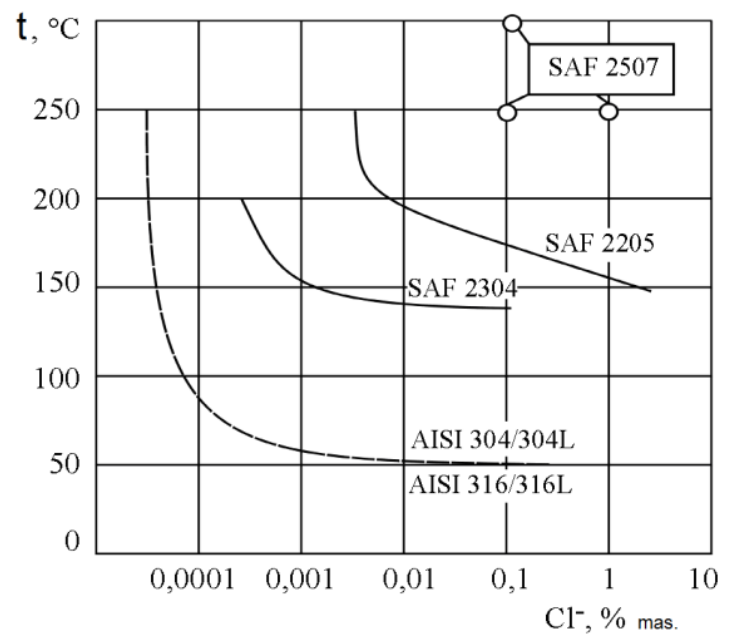

Fig. 2. Comparative characteristics of susceptibility of ferritic-austenitic and austenitic steels to CC depending on temperature and concentration of chlorine ions (the test base: $1000 \mathrm{~h}, \sigma=\sigma_{0.2}$ ) [7]

Comparative tests of $\mathrm{Cr}-\mathrm{Ni}-\mathrm{Mo}$ steels, i.e. austenitic $316 \mathrm{~L}$ and duplex 2205 steels and their welded joints for resistance to erosion performed by various investigators in a $3.5 \% \mathrm{NaCl}$ solution with abrasive components (silicon carbide and sand at various combinations of their concentration) at various motion velocities and estimation of erosion damages by electrochemical, gravimetric and metallographic methods have shown higher erosion resistance of the duplex steel [10].

\section{INNOVATIVE ELABORATIONS FOR IMPROVING CORROSION RESISTANCE OF THE TUBES MADE OF DUPLEX STEELS OF A NEW GENERATION}

In order to further raise corrosion resistance and service reliability of the tubes made of duplex and super-duplex steels of a new generation in accordance with consumer requirements to the NPP heat exchanging equipment, comprehensive scientific and technological studies were conducted at Centravis Production Ukraine JSC, Nikopol, the leading Ukrainian producer of stainless steel tubes.

The studies were based on the principle of grain boundary design of materials [11-14] consisting in the formation of a steel structure with a maximum possible content of special grain boundaries of $\Sigma 3^{\mathrm{n}}$ types known in the theory of lattices with matching nodes featuring a reduced specific surface energy and an increased corrosion resistance during deformation and thermal treatment operations involved in the tube manufacture.

Billets from COGNE, Italy, and Dniprospetsstal JSC, Ukraine, were used in the tube manufacture. The billet production technology was developed jointly by specialists of metallurgical and tube producing enterprises [15].

The innovative technology of manufacturing tubes of duplex and super-duplex steels differs from the conventional technology by application of an intense deformation pressures when rolling tubes to the finished size, reduced temperature of quenching tubes of intermediate sizes and applying double quenching of the final size tubes according to the developed technological variants [16].

The new technology provides improved steel quality by homogenizing its chemical composition and special structural state:

- complete dissolution of adverse excess phases;

- obtaining the maximum possible content of lowenergy $\gamma-\gamma$ special grain boundaries of $\Sigma 3^{\mathrm{n}}$ type (more than $65 \%$ ) in a less corrosion resistant austenitic component of the steel (Fig. 3) at an equal ratio of austenite and ferrite phases;

- increase in the content of low-energy special boundaries of $\alpha-\alpha$ grains in the ferritic component of the steel (marked by dots and circles in the highlighted region of Fig. 4,a);

- occurrence of special phase interphase $\alpha-\gamma$ boundaries with the presence of quaternary joints as a result of phase transformations (indicated by arrows in Fig. 4,b) with a decreased specific surface energy compared with the usual interphase boundaries.

It should be noted that the special low-energy $\alpha-\alpha-$ and $\alpha-\gamma$-boundaries in $\mathrm{Cr}$-Ni-Mo ferritic-austenitic steels have been found for the first time. Tthere are no such data in literature.

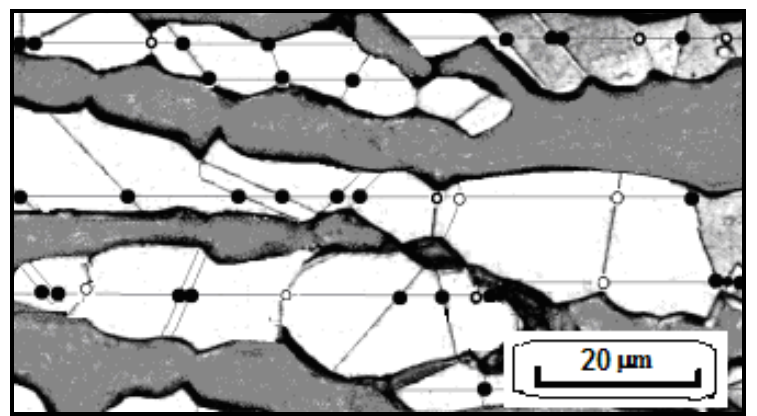

Fig. 3. Increased content of $\gamma-\gamma S B$ of $\Sigma 3^{n}$ type in the structure of $02 \mathrm{Cr} 22 \mathrm{Ni} 5 \mathrm{NMo} 3$ steel tubes made according to the innovative technology: - - SB; O - boundaries of a general type 

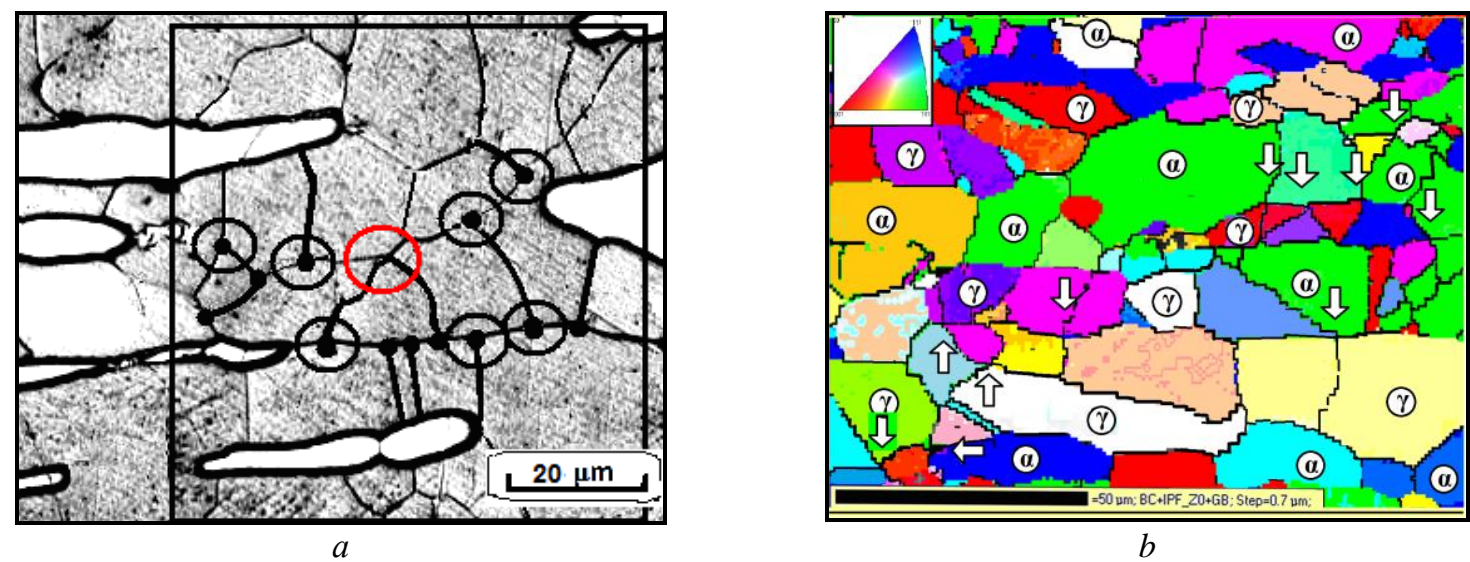

Fig. 4. Increased content of $\alpha-\alpha$ special boundaries in the ferrite component (a) and special interphase $\alpha-\gamma$ boundaries $(b)$ in the structure of $02 \mathrm{Cr} 22 \mathrm{Ni} 5 \mathrm{NMo} 3$ steel tubes manufactured according to the developed technology

The comprehensive corrosion studies of 02Cr22Ni5NMo3 steel tubes manufactured according to the innovative technology included the following specimen tests:

- for resistance to pitting corrosion: at temperatures from 20 to $45^{\circ} \mathrm{C}$ in a $6 \% \mathrm{FeCl}_{3}$ solution according to the ASTM G-48 method. Specific weight loss of the specimen in $72 \mathrm{~h}$ testing which should not exceed $0.0001 \mathrm{~g} / \mathrm{cm}^{2}$ was taken as the criterion of PC resistance;

- for resistance to $\mathrm{CC}$ : with $\mathrm{C}$-shaped spring specimens in a boiling $44 \% \mathrm{MgCl}_{2}$ solution at $155^{\circ} \mathrm{C}$ according to the ASTM G-36 method. The time to formation of first cracks in the specimen surface visible at a $\times 30$ magnification was taken as the criterion of $\mathrm{CC}$ resistance;

- for erosion resistance: by the gravimetric method in an autoclave in a stream of NACE solution containing chloride and hydrogen sulfide $(5 \%$ $\mathrm{NaCl}+0.5 \% \mathrm{CH}_{3} \mathrm{COOH}+\mathrm{H}_{2} \mathrm{~S}$ (saturated) $+1 \%$ abrasive (quartz sand of $0.14 \mathrm{~mm}$ fraction) at temperature of $30{ }^{\circ} \mathrm{C}$, pressure of $0.5 \mathrm{MPa}$ and flow rate of $4.1 \mathrm{~m} \cdot \mathrm{s}^{-1}$;

- service tests were performed at the Dniproazot JSC chemical enterprise in the heat exchanging equipment of the caustic soda production unit.
It was established that the developed technology provided an significant improvement of the complex of corrosion properties of tubes made of the duplex steel [12-14, 16-18].

Resistance to pitting corrosion has increased which was manifested by the increase in the temperature threshold of pitting resistance of the specimens (from 30 to $40{ }^{\circ} \mathrm{C}$ ) and a significant (up to 160 times) decrease in the corrosion rate (Table 2). This was achieved through increasing corrosion resistance of the austenitic phase which is usually less corrosion resistant in these conditions (Fig. 5).

Specimens of austenitic steel tubes have shown a lower resistance to pit corrosion in these tests. They were able to withstand the tests just at $25^{\circ} \mathrm{C}$. Specific weight loss in the specimens was $0.05 \mathrm{~g} / \mathrm{cm}^{2}$ at $40{ }^{\circ} \mathrm{C}$, i.e. it was $\approx 1000$ times more than that of the duplex steel tubes.

The C-shaped spring specimens of $02 \mathrm{Cr} 22 \mathrm{Ni} 5 \mathrm{NMo} 3$ steel tubes manufactured according to the new technology have not shown crack formation during $250 \mathrm{~h}$ of tests at tensile stresses of $270 \mathrm{MPa}$ while corrosion cracking appeared after $24 \mathrm{~h}$ of testing the ring specimens taken from the tubes made of $03 \mathrm{Cr} 17 \mathrm{Ni} 14 \mathrm{Mo} 3$ austenitic steel and straightened at a $5 . .7 \%$ deformation.

Table 2

Influence of manufacturing technology on structure and corrosion resistance of $02 \mathrm{Cr} 22 \mathrm{~N} 5 \mathrm{NMo} 3$ steel tubes

\begin{tabular}{|c|c|c|}
\hline Technology & Pitting rate at $40{ }^{\circ} \mathrm{C}, \mathrm{g} / \mathrm{cm}^{2}$ & Time to pitting, hr \\
\hline Conventional & $0.0005 \ldots 0.001$ (middle 0.0075$),$ pitting & $50 \ldots 100$ \\
\hline Innovating & $0.000036 \ldots 0.000058$ (middle 0.000047$),$ no pitting & $>250$ \\
\hline
\end{tabular}

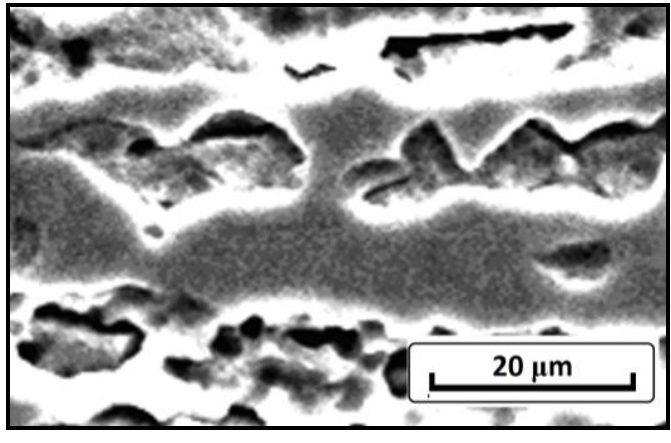

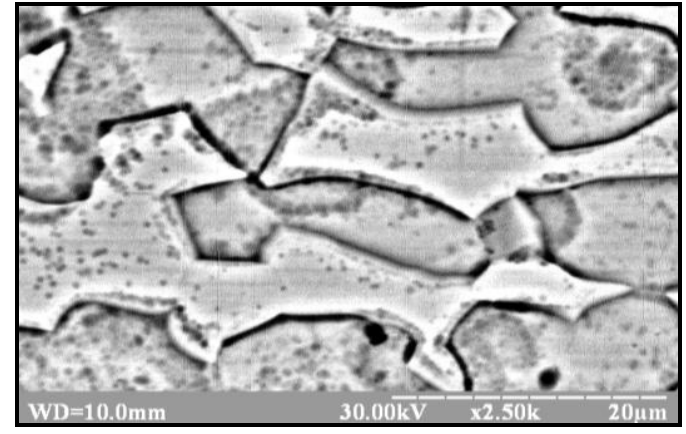

Fig. 5. Pitting in the austenitic component of the structure of tubes made of 02Cr22Ni5NMo3 steel according to the conventional technology $(a)$ and absence of pitting in the tubes made by the innovated technology $(b)$ 
The tubes made of $02 \mathrm{Cr} 22 \mathrm{Ni} 5 \mathrm{NMo} 3$ steel according to the innovative technology showed high resistance to erosion as well. The rate of their specimen erosion was $0.0025 \ldots 0.0045 \mathrm{~mm} /$ year and the specimens taken from the tubes made of a common $08 \mathrm{Cr} 18 \mathrm{Ni10Ti}$ austenitic steel have shown erosion of $0.035 \ldots 0.074 \mathrm{~mm} /$ year, i.e. 25...30 times higher.

The service testing of $02 \mathrm{Cr} 22 \mathrm{Ni} 5 \mathrm{NMo} 3$ steel tubes in the heat exchanging equipment at Dniproazot JSC (in a medium of a concentrated water-steam mixture of alkali and sodium chloride with abrasive particles at $150{ }^{\circ} \mathrm{C}$ and pressure of $2 \mathrm{MPa}$ ) have shown a 3 times higher corrosion resistance compared to the commercially used $08 \mathrm{Cr} 18 \mathrm{Ni10Ti}$ steel tubes [18].

Analysis of the results obtained in the comprehensive study of tubes made of duplex steels based on the innovative technology using the principle of grain boundary design of materials has shown a significant role of special boundaries in raising the corrosion resistance.

The positive effect of special boundaries on corrosion processes occurring at the grain boundaries, at the interphase ferrite-austenite boundaries and in the steel as a whole is due to the following:

- reduced SB surface energy: the specific surface energy was $814 \mathrm{erg} / \mathrm{cm}^{2}$ for the common-type boundaries in the austenitic chromium-nickel $18 \ldots 8$ grade steel and $19 \mathrm{erg} / \mathrm{cm}^{2}$ for the $\Sigma 3^{\mathrm{n}} \mathrm{SB}$, i. e. 47 times lower. Calculations using the Herring equation have shown that the specific surface energy of the $\alpha-\alpha$ $\mathrm{SB}$ in the ferrite component of the duplex steel was $27 . . .35 \mathrm{erg} / \mathrm{cm}^{2}$ which is 25 times lower than that of the $\alpha-\alpha$ boundary of general type $\left(780 \mathrm{erg} / \mathrm{cm}^{2}\right)$;

- reduced segregation of harmful impurities at special boundaries and absence of precipitation of the $\sigma$-phase and chromium and molybdenum carbides during provocative heating.

The innovative technology of production of tubes of improved corrosion resistance and operational reliability made of duplex and super-duplex steels of a new generation has been mastered and implemented at Centravis Production Ukraine JSC. It provides an improvement in qualitative characteristics of tubes and promotes expansion of their application areas.

\section{CONCLUSIONS}

1. The results obtained in the above studies and development works have shown that in terms of the complex of corrosion and operational properties, the tubes made of Cr-Ni-Mo ferritic-austenitic steels of a new generation significantly exceed the tubes made of Cr-Ni-Mo austenitic steels of 03Cr17Ni14Mo3 (316 L) type which are used at present in the NPP heat exchanging equipment and are prone to corrosion failures.

2. An innovative technology of making tubes of $02 \mathrm{Cr} 22 \mathrm{Ni} 5 \mathrm{NMo} 3$ duplex steel based on the principle of grain boundary design of materials has been developed. It ensures improvement of corrosion resistance of tubes:

- an up to 160 times reduction of the pitting corrosion rate;

- a raise of the temperature threshold of pitting resistance from 30 to $40{ }^{\circ} \mathrm{C}$;
- an up to a 2.5 time longer time to corrosion cracking of the specimens tested in a boiling $\mathrm{MgCl}_{2}$ solution according to ASTM G-36 method.

3. The essential role of special low-energy intergranular and interphase boundaries played in improvement of the corrosion resistance of the duplex steel tubes was demonstrated.

4. High corrosion resistance and operational reliability of the tubes manufactured of ferriticaustenitic steels of a new generation by Centravis Production Ukraine JSC make it possible to recommend application of these tubes in the heat exchanging equipment of nuclear power plants.

\section{REFERENCES}

1. В.Н. Воеводин, А.С. Митрофанов, С.В. Гоженко, Р.Л. Василенко и др. Анализ данных контроля теплообменных труб парогенераторов ПГВ-1000 на ЮУАЭС // Вопросы атомной науки и техники. Серия «Физика радиационных повреждений $и$ радиационное материаловедение». 2018, №5(117), c. $82-86$.

2. S. Jacques, J. Peultier, J.C. Gagnepain, and P. Soulignac. Corrosion resistance of duplex stainless steels in thermal desalination plants // Corrosion NACE conference, March 16-20, 2008, p. 17-21.

3. T.D. Clark. An analysis of microstructure and corrosion resistance in underwater friction stir welded 304L stainless steel. 2005, p. 53-54.

4. J.P. Audoard, M. Verneau, J. Groski. Corrosion Performance and Filed Experience with Super Duplex and Super Austenitic Stainless Steels in FGD Systems // $12^{\text {th }}$ International Corrosion Congress, Houston, USA, 1993, p. 131-138.

5. J. Charles, P. Chemelle. The history of duplex developments, nowadays DSS properties and duplex market future trends // $8^{\text {th }}$ Duplex stainless Steels conference, 13-15 Oct. 2010, Beaune, France, 2010, p. 99-107.

6. B. Walden, J.M. Nicholls. The Sandvik duplex family of stainless steels. Summary of data // Proc. of the VI Korrosyon Sempozyumu Bildiriler Kitabi (4-7 Kasim 1998, Turkey), 1998, p. 100-122.

7. W.-T. Tsai, S.-L. Chou. Environmentally assisted cracking behavior of duplex stainless steel in concentrated sodium chloride solution // Corros. Sci. 2000, N 42, p. 1741-1762.

8. R. Raman. Studies on Flow Induced Localized Corrosion of 304 Austenitic \& 2205 Duplex Stainless Steel Welds in $3.5 \% \mathrm{NaCl}$ with or Without Abrasive Particles // Indian Institute of Technology. Bombay, 2005, p. 76-69.

9. Duplex stainless steel welding. Best practices. www. stainless-steel-world.

10. Heejoon Hwang and Yongsoo Park. Effects of Heat Treatment on the Phase Ratio and Corrosion Resistance of Duplex Stainless Steel // Materials Transactions. 2009, v. 50, N 6, p. 1548-1552.

11. T. Watanabe. Grain boundary engineering: historical perspective and future prospects // J. Mater. Sci. 2011, v. 46, p. 4095.

12. В.И. Большаков, Т.А. Дергач, Г.Д. Сухомлин, С.А. Панченко. Применение зернограничного кон- 
струирования для повышения коррозионной стойкости труб из ферритно-аустенитных сталей // Коррозия: материаль, защита. М.: «ООО Наука и технологии», 2014, №7, с. 20-26.

13. S.A. Panchenko. Improving the Reliability of Duplex Steel Pipe // Steel in Translation. 2015, v. 45, N 2, p. 153-160.

14. В.И. Большаков, С.А. Панченко, Т.А. Дергач. Научные и технологические методы повышения коррозионной стойкости труб из дуплексных сталей: Монография. Днепр: «Литограф», 2016, $135 \mathrm{c}$.

15. А.И. Панченко, А.В. Король, А.В. Жайворонок, Л.В. Тур, С.А. Панченко, А.Е. Балев. Освоение технологии производства трубной заготовки из коррозионно-стойкой стали дуплексного класса // Сталь. 2012, №9, с. 49-52.

16. Т.О. Дергач, Г.Д. Сухомлин. Теоретичні та технологічні основи розробки інноваційних технологій виробництва труб 3 високолегованих сталей // Фізико-хімічна механіка матеріалів: Спец. випуск №12. Проблеми корозї̈ та протикорозійного захисту матеріалів. Львів, 2018, с. 153-158.

17. В.И. Большаков, Т.А. Дергач, С.А. Панченко. Коррозионные исследования труб из ферритноаустенитной стали после термической обработки по действующей и разработанной технологиям // Металлургическая и горнорудная промышленность. 2012, №6, c. 60-63.

18. С.А. Панченко А.Е. Балев, Т.А. Дергач. Эксплуатационные испытания труб повышенной коррозионной стойкости из стали 02Х22Н5АМ3, изготовленных по инновационной технологии: Збірник статей учасників $X X X$ Міжнародноі науково-практичної конферениії «Інновачійний потенціал світової науки-XXI сторіччя». Запоріжжя, 2015, с. 23-27.

\title{
ПЕРСПЕКТИВЫ ПРИМЕНЕНИЯ ТРУБ ИЗ ДУПЛЕКСНЫХ СТАЛЕЙ НОВОГО ПОКОЛЕНИЯ В ТЕПЛООБМЕННОМ ОБОРУДОВАНИИ АЭС
}

\author{
Т.А. Дергач, Г.Д. Сухомлин, С.А. Панченко, Н.Е. Калинина, А.Е. Балев, А.В. Красюк, В.Т. Калинин
}

На основании анализа научно-технической литературы и результатов комплексных исследований научно обоснована перспективность использования труб из ферритно-аустенитных (дуплексных) сталей нового поколения, которые изготавливает по разработанной инновационной технологии ЧАО «Сентравис Продакшн Юкрейн», в теплообменном оборудовании АЭС. Сравнительные исследования коррозионной стойкости труб из аустенитных Cr-Ni- и Cr-Ni-Mo-сталей и дуплексной стали 02X22H5AM3 (UNS S 31803) показали значительно более высокую стойкость последних против межкристаллитной, питтинговой, язвенной, щелевой коррозий, коррозионного растрескивания и эрозии. Впервые установлено наличие в структуре ферритно-аустенитных сталей специальных низкоэнергетических границ зерен $\gamma-\gamma, \alpha-\alpha$ и межфазных границ $\alpha-\gamma$, характеризующихся повышенной коррозионной стойкостью и способствующих повышению стойкости стали в целом.

\section{ПЕРСПЕКТИВИ ЗАСТОСУВАННЯ ТРУБ ІЗ ДУПЛЕКСНИХ СТАЛЕЙ НОВОГО ПОКОЛІННЯ В ТЕПЛООБМІННОМУ УСТАТКУВАННІ АЕС}

\author{
Т.О. Дергач, Г.Д. Сухомлин, С.А. Панченко, Н.С. Калініна, А.С. Балєв, А.В. Красюк, В.Т. Калінін
}

На основі аналізу науково-технічної літератури і результатів комплексних досліджень науково обгрунтована перспективність застосування труб 3 феритно-аустенітних (дуплексних) сталей нового покоління, які виготовляє за розробленою інноваційною технологією ПрАТ «Сентравіс Продакшн Юкрейн», у теплообмінному обладнання АЕС. Порівняльні дослідження корозійної тривкості труб з аустенітних СrNi- і Cr-Ni-Мо-сталей і дуплексної сталі 02Х22H5AM3 (UNS S 31803) показали значно вищу тривкість останніх проти міжкристалітної, пітінгової, виразкової, щілинної корозій, корозійного розтріскування i ерозії. Вперше встановлено наявність у структурі феритно-аустенітних сталей спеціальних низькоенергетичних границь зерен $\gamma-\gamma$ i $\alpha-\alpha$ i міжфазних границь $\alpha-\gamma$, які характеризуються підвищеною корозійною тривкістю та сприяють підвищенню корозійної тривкості сталі в цілому. 